внеурочных экскурсий с посещением специализированных выставок по тематике занятий. В совокупности предложенный подход должен позволить обеспечить духовно-нравственное развитие, воспитание и социализацию школьников.

Недостатком подхода можно считать отсутствие обучения вопросам информационной безопасности в младших классах.

Таким образом, в настоящее время вопросам обучения кибербезопасности в школе уделяется недостаточно внимания, однако работы по совершенствованию образовательного процесса ведутся.

$$
* * *
$$

1. Федеральный закон от 29.12.2010 N 436-Ф3 "О защите детей от информации, причиняющей вред их здоровью и развитию". [Электронный ресурс] - Режим доступа: http://www.consultant.ru

2. Федеральный закон Российской Федерации от 27.07.2006 №149-Ф3 «Об информации, информационных технологиях и о защите информации» [Электронный ресурс] - Режим доступа: www.consultant.ru

3. Богатырева Ю.И., Калугина Е.С. Угрозы информационного воздействия на учащихся и методы противодействия им в образовательной организации [Электронный ресурс] - Режим доступа: http://rrpedagogy.ru/journal/article/822/

4. Кочемиров Н.Н. Особенности изучения вопросов информационной безопасности в школьном курсе информатики [Электронный ресурс $\quad$ Режим https://урок.pф/library/osobennosti_izucheniya_voprosov_informatcionnoj_bezop_093433.html

5. Бочаров М.И. Методика обучения информационной безопасности старшеклассников: о содержании обучения в школьном курсе информатики / М.И. Бочаров, И.В. Симонова // Пространство и время. - 20014. №3 (17) [Электронный ресурс] - Режим доступа: https://cyberleninka.ru/article/n/metodika-obucheniyainformatsionnoy-bezopasnosti-starsheklassnikov

\title{
Bashmakova N.I. \\ Professional training for the judiciary through the prism of the Federal State Educational Standard
}

The North Western branch of the Federal State Budget-Funded Educational Institution of Higher Education "The Russian State University of Justice" (Russia, Saint-Petersburg)

doi: 10.18411/trnio-01-2022-163

\section{Abstract}

The article deals with the problem of professional training for the judiciary. The object of the study is the professional training of specialists for the judiciary in a higher education institution. The subject of the study is the requirements of the Federal State Educational Standards to the professional training of specialists for the judiciary in the context of the new technological order. The purpose of the study is to analyze professional training for the judiciary in the context of the existing federal state educational standards.

Keywords: professional training for the judiciary, higher education institution, requirements, specialists, the Federal State Educational Standard.

\section{Аннотация}

Статья посвящена проблеме профессиональной подготовки специалистов для судебной системы. Объектом исследования является профессиональная подготовка специалистов для судебной системы в высшем учебном заведении. Предметом исследования служат требования ФГОС ВПО к профессиональной подготовке специалистов для судебной системы в условиях нового технологического уклада. Цель исследования заключается в том, чтобы проанализировать профессиональную подготовку специалистов для судебной системы в контексте действующих федеральных государственных образовательных стандартов.

Ключевые слова: профессиональная подготовка кадров для судебной системы, высшее учебное заведение, требования, специалисты, Федеральный государственный образовательный стандарт. 


\section{Introduction}

Globalization and integration challenge the Russian society to develop a modern professional in demand for the judicial system. The current Federal State Educational Standard of Higher Education should be implemented within a competence-based approach, as required by the relevant professional standards, in accordance with the existing regulations. Meanwhile, it should be emphasized that some researchers (D.I. Kravtsov, V.M. Morgunov, J.S. Pozdnyakova, etc.) point out that professional education and applied professional activity are still disconnected from each other. Consequently, there are discrepancies between: the social order for the formation of a competent specialist for the judicial system and the insufficient level of professional readiness of university graduates for professional activities; between the labor market requirements for the level of professional competence of a specialist for the judicial system and the inconsistency between professional and educational standards of higher education. In the light of the identified discrepancies and the scientific problem formulation, the article's topic has been formulated: "Professional training of specialists for the judicial system through the prism of the Federal State Educational Standard".

Given that the problem of training qualified personnel for the judicial system of the Russian Federation is a priority for the state in the field of education, the relevance of the topic stated in the article is beyond question. The theoretical basis of the research was based on the competence approach, promoting the formation of future specialists' experience of solving professional tasks independently, constituting the content of education (V.I. Baidenko, I.A. Zimnyaya, V.V. Serikov, etc.), the systemic approach, considering education as an integral process (A.N. Averyanov, V.G. Afanasyev, V.S. Ilyina, B.F. Lomov, V.A. Slastenin, etc.). The key principles of professional education (A.K. Markova, A.V. Leontiev, etc.) have also been used.

The purpose of the study allowed us to outline a range of research methods. The key methods of research have been theoretical methods, implying the study and analysis of the Federal State Educational Standard for the training direction 40.05.04 "Judicial and prosecutorial activity" for further modeling the process of incorporating modern information technology in teaching social and humanitarian complex disciplines in a law school; and empirical methods, implying observation. The theme stated in the article leads to the following logic of the article: to specify the concept of professional training of specialists for the judiciary in relation to this study, to analyze the Federal State Educational Standard for the training specialists for the judiciary and to identify the key functions and requirements for a specialist for the judiciary, based on the available standard.

\section{Materials and methods}

In the course of the study the research findings of scientists on the issues discussed, the results of the research experience of the author of the article have been used. The analysis of the available sources on the issue under study allows to state that professional training can be interpreted in a broad and narrow sense. Professional training for the judiciary in the broad sense is understood in the article as obtaining legal education in the sense given in the preamble to the Law of the Russian Federation "On Education". The preamble states: "Under the acquisition of education by a citizen (student) is understood the achievement and confirmation of his educational qualification, which is certified by an appropriate document" [2]. Based on the above, it is seen that the focus of professional training of specialists for the judicial system should be consistent with the current socio-economic and political challenges, to be ahead of the curve. This postulate becomes particularly important in the course of improving the content of professional training in the context of the transition of society to a new technological way of life, when the requirements for a specialist are conditioned by the functions performed and professional tasks. Meanwhile, it should be worth highlighting that the goal of professional training of specialists for the judicial system is to achieve quality education, which, according to A.N. Dzhurinsky [4], is defined from the perspective of positive changes in the procedural and performance aspects of education. At the same time, within the framework of competency-based approach, which is normatively fixed as the basic one in the Federal State Educational Standard of Higher Professional Education, the resulting aspect of professional training is reflected in the readiness of the university graduates to arrange professional 
activities by updating the formed key competencies; the procedural aspect of professional training covers the requirements for its immediate organization in the educational process [3]. In this connection, the point of view of G.S. Abdrakhmanova [1], who defines the quality of professional training (as a process) in the projection of assessing the compliance of the educational system in its personnel, material and technical, information, scientific and methodological potential with the requirements and its ability (in the resultant aspect) to ensure the achievement of results, which are determined by requirements for graduate training quality, seems essential. In view of the above, we propose to define the line between process and result within the boundaries of professional training for the judiciary. Based on V.A. Slastenin's position [7], who understands the term "training" as a dynamic process aimed at achieving a result, which is readiness, we can establish the need to organize professional training in terms of providing the required conditions. Such conditions should be created in higher education institution in order to obtain the result, which is determined by the level of compliance of personal-professional readiness of graduates with the normatively set and socially conditioned requirements.

In our opinion, the professional training of future specialists for the judicial system, being an integrated part of the system of the legal professional education, is a multifunctional process of mastering competencies (general cultural, professional, special) in accordance with the requirements of the Federal State Educational Standard of Higher Professional Education, qualification requirements for specialists and types of activities and professional tasks. Referring to the key functions and professional tasks, it can be claimed that in today's realities, the formation of a professional profile model for the judiciary is of particular importance. According to V. Y. Koldin [6], the most in-demand model could be not only the wide profile lawyer model, but also the search for various forms of specialization of university graduates able to be realized in the organizational and legal form of various professions. Analyzing the Federal State Educational Standard of Higher Professional Education, we point out that in fact it represents a preparation model for a future specialist for the judicial system, fixing in its functional field the description of the structure and content of the educational process, resource and information support, requirements to the conditions, results and quality of mastering the basic educational programs.

The study of the available normative legal documents allows us to conclude that the Ministry of Education and Science of the Russian Federation has approved three federal state educational standards of higher education at the specialist's level. These include the following: The Federal State Educational Standard of Higher Education of the Specialist's Degree in "Law Enforcement"; Federal State educational standard for higher education at the specialist level specializing in 40.05.01 "Legal support for national security"; Federal State Educational Standard for Higher Education at the Specialist Level for the Specialty 40.05.04 "Judicial and Prosecutorial Activities" [8]. These federal state educational standards of higher education at the specialist level stipulate that when designing and implementing a specialist program, the educational organization is guided by the specific type(s) of professional activity, for which the specialist is being trained and in accordance with which the specialization is selected, based on the labor market needs, research and material and technical resources of the organization.

The Federal State Educational Standards for Higher Legal Education define the content of the educational program and its division into two parts, basic and variative. Upon completion of the disciplines of the basic part of the educational program, students are given the opportunity to choose a specialization, usually after the second year of study. In accordance with the general characteristic of legal education proposed by V. Ershov [5]. The Russian Federation distinguishes between classical and specialized theoretical models of higher legal education. The first model is offered in the structural subdivisions of higher education institutions, i.e., law faculties. The second model is provided in specialized institutions and is determined by enhanced training and in-depth research. It is important to mention that the legal community is currently awaiting the release of an updated new standard to address the shortcomings of previous standards and bridge the gap between the higher legal education received by university graduates and the requirements of employers who note the 
unpreparedness of recent graduates to undertake professional activities in the new socio-economic environment.

In accordance with the requirements of the current standard, a graduate implements such professional activities as law-making, law enforcement, expert and advisory, law enforcement, organizational and managerial, research, etc. within the framework of professional functionality.

It should be underlined that today, when developing a model for a modern specialist, the requirements for a specialist arising from the digital economy need to be taken into account. Let us note that the requirements imposed by the information society on a specialist in today's labor market are worth specifying in more detail.

In our view, such requirements are not only limited to the possession of professional problem-solving thinking, organizational, communicative and other competences, and the needs of personal professional growth, but also to the information culture, which implies the ability to competently use the full range of information technologies in everyday information and legal activities. When applied to the information-legal activity of a specialist for the judiciary, these are such key skills as: 1) to find relevant information in various electronic databases, reference search systems; 2) to carry out information analysis and choose adequate forms of presenting information; 3 ) to use the data obtained in solving specific professional tasks. The key factor of the information culture is an ability and readiness of an individual to master a new way of life determined by the new values of information society. It can be stated that it is the information and legal outlook that should be considered as the key factor in the formation of professional level of legal awareness and legal culture of future lawyers, which allow providing an independent competent professional activity.

The Federal State Educational Standard of Higher Education in the field of training 40.05.04 "Judicial and prosecutorial activities" (specialist level) [8] contains provisions that everyone must be provided with individual unlimited access to one or more electronic library systems (electronic libraries) and to the electronic information and educational environment of the organization. The functioning of the electronic information and education environment is ensured by appropriate means of information and communication technologies and the qualifications of the employees and must comply with the legislation of the Russian Federation. From the above, it can be seen that the target of the informatization of higher legal education is to improve the quality of general legal and informational professional training of specialists for the judicial system.

\section{Results and discussion}

The study has made it possible: 1) to specify the notion of professional training for the judiciary; 2) to analyze existing federal state educational standards; 3 ) to identify the key functions and requirements for a specialist for the judiciary, based on the available standard. The aim of the study has been achieved. This study has shown that the development of information technology in the 21 st century has led to a number of contradictions between the professional practice and the competences of the judiciary specialist in the use of information technology.

$$
* * *
$$

1. Abdrakhmanova, G.S. Quality of Education // Education Quality Management in Conditions of Innovative Economic Development. Naberezhnye Chelny, 2003. C. 253-254.

2. Bashmakova, N.i., Bondarev, V.G. Professional readiness of specialists for the judicial system: genesis and development of the content of the concept//Education Newsletter Consciousness. 2021. T. 23. № 5. C. 34-41.

3. Burlakova I.I. Main approaches to interpretation of education quality in Russia and abroad //Innovations in Education. 2013. № 1. C. 35-39.

4. Dzhurinsky, A.N. Foreign school: current state and development trends. M. 1993. 190 c.

5. Ershov, V. V. Higher legal education and labour law in Russia: Current issues of theory and practice //Labour Law. 2010. № 4. C. 73-76.

6. Koldin, V. Я. The concept of professional training of a lawyer of broad profile // Legal Education and Science. 2009. № 4. C. 10-13.

7. Slastenin, V.A. Psychology and Pedagogy: Textbook for Students of Higher Education Institutions /V.A. Slastenin, V.P. Kashirin. M.: Academia. 2001. 480 c.

8. URL: http://standart.edu.ru/ (accessed 07.12.2021). 